\title{
Effect of political corruption on municipal tax revenues
}

\section{María-Dolores Guillamón ${ }^{a}$, Javier Cifuentes ${ }^{\mathrm{b}}$, Úrsula Faura $^{\mathrm{c}}$, Bernardino Benito $^{\mathrm{d}}$}

$a, b, d)$ Department of Accounting and Finance, Faculty of Economics and Business, Regional Campus of International Excellence "Campus Mare Nostrum", University of Murcia, 30100-Espinardo (Murcia), SPAIN.

c) Department of Quantitative Methods for Economics and Business, Faculty of Economics and Business, Regional Campus of International Excellence "Campus Mare c) Department of Quantitative Methods for Economics and Business,
Nostrum", University of Murcia, 30100-Espinardo (Murcia), SPAIN.

\footnotetext{
${ }^{a}$ Corresponding author.

E-mail address: mdguillamon@um.es
}

\section{A R T I C L E I N F O}

\section{Article history:}

Received 17 January 2020

Accepted 28 February 2020

Available online 1 July 2021

JEL classification:

D73

H20

H71

\section{Keywords:}

Political corruption

Local governments

Tax revenues

\section{A B S T R A C T}

Most research on corruption has been at the national level, because its study at the regional or local level is more complex. Although there are many studies about the relation between corruption and government spending, very few examine the influence of corruption on government revenues, and we have not found any at the subnational level, except the recent Liu \& Mikesell (2019).

Our aim is to analyze political corruption at the municipal level, studying whether the level of revenue of municipal governments is affected by the cases of corruption involving local politicians. Some of the other factors taken into account are political ideology, absolute majority government and the electoral cycle. The sample is a data panel of all the Spanish municipalities with a population of over 50,000 inhabitants for the period 2002-2013.

Our results reveal that municipalities with higher levels of corruption have higher tax revenues in per capita terms.

(C)2021 ASEPUC. Published by EDITUM - Universidad de Murcia. This is an open access article under the CC BY-NC-ND license (http://creativecommons.org/licenses/by-nc-nd/4.0/).

\section{Códigos JEL:}

D73
H20
H71

H71

Palabras clave

Corrupción política

Gobiernos locales

Ingresos fiscales
Efecto de la corrupción política en los ingresos impositivos municipales R E S U M E N

La mayor parte de la investigación sobre la corrupción se ha realizado a nivel nacional, porque su estudio a nivel regional o local es más complejo. Aunque hay muchos estudios sobre la relación entre la corrupción y el gasto público, muy pocos examinan la influencia de la corrupción en los ingresos públicos, y no hemos encontrado ninguno a nivel subnacional, excepto el reciente de Liu \& Mikesell (2019).

Nuestro objetivo es analizar la corrupción política a nivel municipal, estudiando si el nivel de ingresos de los gobiernos municipales se ve afectado por los casos de corrupción que involucran a los políticos locales. Otros factores que se toman en cuenta son la ideología política, el gobierno de mayoría absoluta y el ciclo electoral. La muestra es un panel de datos de todos los municipios españoles con una población de más de 50.000 habitantes para el período 2002-2013.

Nuestros resultados revelan que los municipios con mayores niveles de corrupción tienen mayores ingresos fiscales en términos per cápita

(C)2021 ASEPUC. Publicado por EDITUM - Universidad de Murcia. Este es un artículo Open Access bajo la licencia CC BY-NC-ND (http://creativecommons.org/licenses/by-nc-nd/4.0/). 


\section{Introduction}

An increasing number of studies are addressing the topic of corruption. Many have analyzed its effects on economic development (Mauro, 1995; Dreher \& Herzfeld, 2005; Salinas \& Salinas, 2007; Xu \& Yano, 2017; Apergis \& Apergis, 2017; Christos et al., 2018). Others have shown how it negatively influences the development of democracy and the rule of law (Warren, 2004; Villoria, 2007).

However, most of the research is at the national level and there is very little on corruption at the regional or local level, mainly because it is more difficult to measure corruption in this environment, which means that there are hardly any official indicators, as we will see later.

Corruption affects not only the composition and amount spent by governments, but can also impact public revenues. For example, corruption can reduce tax revenues if it contributes to tax evasion, inappropriate tax exemptions or weak tax administration (Tanzi \& Davoodi, 1997; IMF, 2016). Other studies find that the direct or indirect relation between corruption and tax revenues depends on the specific type of tax (Imam \& Jacobs, 2007). Despite the relevance of the topic, there are few studies in this area, and most of them at the national level.

This lack of attention in the literature to the non-electoral effects of revealed corruption may very probably be due to the lack of appropriate data previously available to investigate these effects.

More specifically, as regards the impact of corruption on the tax system at the local level, as far as we know, only the study of Liu \& Mikesell (2019) has been published; it is also true that the article focuses on American states rather than on municipalities.

This article fills this gap by studying how corruption affects the level of tax revenues at the municipal level.

Following this introduction, section 2 includes a brief discussion on what corruption is and how to measure it; section 3 describes the causes and consequences of corruption. In section 4, the influence of corruption on tax revenues is studied using a data panel that includes all Spanish municipalities with more than 50,000 inhabitants for the period 2002-2013. Finally, the conclusions and further research are presented in section 5 .

\section{Concept and measurement of corruption}

To understand any problem, it is necessary to define and identify it, but this is particularly complicated in the case of corruption because "there is no concept of corruption that is capable of taking in all its forms and, at the same time, being sufficiently rigorous" (Villoria \& Jiménez, 2012, p.114).

Corruption is a complex phenomenon with a wide variety of causes and effects and it is also a structural, moral and cultural problem, so its study is multidisciplinary. The concept of corruption and methods of measurement should be selected according to the aim of the research.

One definition that can be applied in a number of scenarios is that offered by Wainstein $(2003$, p.6): "Corruption occurs when a person unlawfully sets his or her personal interests above those of the people and ideals he or she is committed to serving". Transparency International (2017) considers it as "the abuse of entrusted power for private gain". This last definition is widely used in works on corruption in the public sector where a public official accepts, solicits or induces a bribe from an outsider in order to circumvent public policies and processes of competitive advantage and obtain benefits; or when, even if there has been no bribe, public revenues are stolen or diverted.

We assume that "corruption is a hidden social practice and, as such, difficult to perceive, measure and quantify" (Jiménez \& Villoria, 2008, p.1). To have a reliable measure of the level of corruption, participants in such activities would need to evaluate themselves (Castillo, 2003; Chacón \& Sauma, 2016). In addition, significant resources are needed to discover them. Only cases that come to light will be counted, but many will go unpunished. In order to overcome these drawbacks and gain a better understanding of corruption, alternative methodologies have been developed to measure it and at least provide an approximation of the number of cases, as well as knowledge of the attitudes, values and behavior of citizens and authorities.

Villoria \& Jiménez (2012) establish three ways of measuring corruption. The first is an objective measure that focuses on collecting the number of corruption allegations based on open cases and/or the number of convictions. The other two are subjective; one based on surveys of perceptions of national and foreign investors, specialists and citizens, and the other on victimization surveys, which ask citizens about their direct experiences of bribery or extortion by public officials.

All indices that measure perceptions of corruption do not focus on the extent of corruption, with the added disadvantage that they may be biased, since these perceptions change from country to country and culture to culture. Neither do they indicate the cost of the resources of corruption (in this respect, Atta-Mensah (2016) elaborates a measure to quantify corruption).

Measurement through victimization surveys has the disadvantage that because corruption is a crime, many people, even if they have been involved in corruption, are unwilling to recognize it. The surveys may even be used to express unease with the Government or Public Administration in response to treatment that is considered unfair, even though there may have been no actual abuse of power.

Golden \& Picci (2005) consider that measuring corruption through surveys has some weaknesses. First, the actual degree of reliability of the survey information is largely unknown. Therefore, respondents involved in corruption may have incentives to withhold relevant information, while those not involved may lack accurate information. Second, the reliability of the indices may also deteriorate over time. Given that the indices are published, there is a danger that respondents, instead of reporting on actual corruption, will express what they believe, based on the results of the most recent indices.

Urra (2007) indicates that the perception of corruption by experts is important, even as a direct indicator, although he also points out that the difference between perceived and actual corruption could be large, so it is convenient to take into consideration what the index really measures when drawing conclusions from empirical studies. The main problem is that it is not well known whether what is being measured is corruption or the quality of a legal and judicial system, since a country may have very few data on corruption prosecuted and yet have high levels of corruption if it does not have an adequate detection system and a highly effective judicial model. Hawthorne (2013) states that there are two major limitations when using the perception of corruption as an indicator of corruption, since i) perception of reality is not always a good reflection of reality, and ii) it is not possible to determine clearly how much of the perception is associated with relations between individuals and institutions. 
Despite the limitations of surveys, the reality is that corruption is currently measured in the main by subjective indices that assess perception, given the difficulties of obtaining objective data (examples of these indices are those elaborated by Transparency International, the World Bank and the World Economic Forum).

\section{Causes and consequences of corruption}

In recent decades, and especially since the 1990s, the issue of corruption has generated great interest, which has led to the publication of many papers. These can be classified mainly into two groups: those that investigate the causes of corruption and those that focus on the consequences it can have on economic variables, although, as Enste \& Heldman (2017) state, it is very difficult to distinguish between the consequences and causes of corruption.

Various studies put forward many determinants to explain corruption (Soto, 2003; Brodschi et al., 2008; Castañeda, 2016; Enste \& Heldman, 2017). Table 1 presents the main causes detected and the effect found empirically on corruption. These include socio-economic (unemployment, GDP per capita, education, etc.), institutional (public sector salaries, number of political parties, level of civil participation, press freedom, independence of the judicial system, centralization of power, etc.), and socio-cultural (religion, race, etc.) causes.

Table 1

Main causes of corruption

\begin{tabular}{|c|c|}
\hline Cause & Effect on corruption \\
\hline $\begin{array}{l}\text { Size and structure of government } \\
\text { Knack \& Azfar (2003); Kunicova \& Rose- } \\
\text { Ackerman (2005); Lambsdorff (2006); Mocan } \\
\text { (2008); Goel \& Nelson (2011) }\end{array}$ & No consensus \\
\hline $\begin{array}{l}\text { Democracy and the political system } \\
\text { Kunicova \& Rose-Ackerman (2005); Rock } \\
\text { (2009); Pellegrini \& Gerlagh (2008); Boehm } \\
\text { (2015); Kaufmann \& Kraay (2016) }\end{array}$ & $\begin{array}{l}\text { Strong and negative } \\
\text { when combined with } \\
\text { factors such as quality } \\
\text { and time of operation of } \\
\text { institutions }\end{array}$ \\
\hline $\begin{array}{l}\text { Quality of the institutions } \\
\text { Djankov et al. (2002); Dreher et al. (2009); } \\
\text { Kaufmann \& Kraay (2016) }\end{array}$ & Strong and negative \\
\hline $\begin{array}{l}\text { Level of competence and economic } \\
\text { freedom } \\
\text { Wei (2000); Sung \& Chu (2003); Gerring \& } \\
\text { Thacker (2005); Saha et al. (2009) }\end{array}$ & Strong and negative \\
\hline $\begin{array}{l}\text { Recruitment and salaries } \\
\text { Treisman (2000); Van Rijckeghem \& Weder } \\
\text { (2001); Van Veldhuizen (2011); Benito et al. } \\
\text { (2018) }\end{array}$ & No consensus \\
\hline $\begin{array}{l}\text { Press freedom and the judiciary } \\
\text { Lederman et al. (2005); Freille et al. (2007); } \\
\text { Pellegrini \& Gerlagh (2008) }\end{array}$ & Strong and negative \\
\hline $\begin{array}{l}\text { Sociocultural determinants } \\
\text { Mauro (1996); Treisman (2000); Paldam } \\
\text { (2001); Lambsdorff (2006); Shabbir \& Anwar } \\
\text { (2007); Gächter \& Schulz (2016) }\end{array}$ & $\begin{array}{l}\text { No consensus in certain } \\
\text { areas such as education }\end{array}$ \\
\hline $\begin{array}{l}\text { More regulation, laws and taxes } \\
\text { Sanyal et al. (2000); Cerqueti \& Coppier } \\
\text { (2011); Báez (2013) }\end{array}$ & Strong and negative \\
\hline $\begin{array}{l}\text { Natural resource endowment } \\
\text { Ades \& DiTella (1999); Tanzi \& Davoodi } \\
\text { (2000); Bhattacharyya \& Hodler (2010) }\end{array}$ & $\begin{array}{l}\text { Strong and positive if the } \\
\text { quality of democratic } \\
\text { institutions is weak }\end{array}$ \\
\hline
\end{tabular}

The consequences of corruption have also been widely debated in recent decades. Although there is a unanimous moral condemnation of corruption, some economists contem- plate it to have positive aspects on the economy (Leff, 1964; Lui, 1985; Huang, 2016). For example, Enste \& Heldman (2017, p.24) see "corruption as an opportunity to allocate scarce resources to the companies that are most willing to pay and therefore most productive. (...), consider corruption as a means of increasing the efficiency of an economy and avoiding time-consuming bureaucratic processes".

Most empirical studies detect a negative impact of corruption on growth and economic development in the regions. Thus, Mynt (2000), Kargbo (2006) and Matsheza (2007), among others, stress that corruption provides public employees with incentives to make the bureaucratic process more inefficient and to obtain personal income in exchange for speeding it up; at the same time, it reduces the government's capacity to design appropriate policies, so generating a loss of credibility, which further favors corruption. Also as a result of corruption, there is a greater concentration of wealth (Mynt, 2000) - it is often those who have the necessary resources to participate in corruption networks who benefit from them, which leads to greater inequality. In this line, Alcaide \& Larrú (2007) find a significant relationship between the Corruption Perception Index and the Gini Index. Christos et al. (2018) demonstrate that there is a positive linear relationship between the growth rate of GDP per capita and the reduction of levels of corruption in all European countries, so reducing the level of corruption in one country will lead to a significant increase in that country's GDP and wealth. The impact of corruption on government accounts is another aspect that has been studied extensively in the literature. On the public expenditure side, a significant part of the works highlights the fact that corruption generates huge incentives in this field, since public employees themselves can allocate more funds to activities in which it is easier to appropriate a part of them. LaPalombara (1994) argues that fiscal spending as a percentage of GDP in a set of countries is positively correlated with corruption. Gupta et al. (2002) note that corrupt governments spend a smaller proportion of their budgets on education and health. This is justified by the fact that education and health are not normally associated with large public investment projects from which one can derive personal benefit. Liu \& Mikesell (2014) show that corruption and regional spending are positively correlated. They conclude that the most corrupt regions tend to spend more money on areas prone to corrupt practices such as construction and roads, and less on education and health.

Research on the relationship between revenue and corruption has been carried out at the country level. Tanzi \& Davoodi (1997) and Johnson et al. (1998) show that countries with more corruption tend to have lower tax revenues relative to their GDP. The greater the corruption, the lower the tax collection (Gupta et al., 2002) as a result of greater tax evasion, since the cost of being caught would be lower insofar as one can bribe the public official responsible for reporting or sanctioning. Therefore, there are fewer taxpayers, or they pay less, so revenue decreases. Hwang (2002) studies whether corruption influences government revenues and finds an inverse relationship between the two variables, but when he studies the relationship between different types of taxes he obtains a positive association with international trade taxes. Ghura (2002) finds empirical evidence that negatively relates corruption and government revenues in subSaharan African countries. Imam \& Jacobs (2007), depending on the type of tax analyzed, find a positive, negative or non-significant relationship.

In general, most of the work on corruption has used country samples and there are very few studies on corruption at 
the municipal level, mainly because of the difficulty of finding adequate and reliable data on corruption for municipalities (Ferraz \& Finan, 2011), despite the fact that these have the advantage of being more homogeneous and that it is possible to have more data (Pettersson-Lidbom 2001; Ashworth et al., 2005). In this regard, Liu \& Mikesell (2019) is of particular relevance, as they examine the extent to which public corruption influences the tax structure of American states.

At the local level, we can cite Ferraz \& Finan (2008), who analyze the reaction of voters to local corruption in Brazil, concluding that these not only care about corruption, but once empowered with the information that describe cases of corruption, update their prior beliefs and punish corrupt politicians at the polls. Liu \& Lin (2012) focus on the Chinese provinces and use cases committed by public officials and filed by judicial bodies to measure corruption in the provinces.

In Jiménez (2013) a model is estimated that determines that the larger the size of the municipality, or the greater the stability in the composition of the mayor's office, or the greater the diversity in the number of existing parties, the greater the possibility of having cases of local corruption. Jiménez \& García (2012, 2016) explore how corruption has affected voting results and political participation and whether this depends on which political party is accused of corruption. Albalate \& Jiménez (2018) analyze the relationship between levels of transparency at the local level and corruption, indicating that a lack of transparency at the local level can hide corrupt actions. Benito et al. (2015) study corruption in 110 Spanish municipalities and their results show the impact of transparency, salaries and population (as an indicator of urbanization) on corruption. The lower the transparency, the greater the likelihood of corruption; higher salaries ensure less corruption and larger municipalities have more corruption. López-Valcárcel et al. (2017) determine, by means of a spatial econometric model, that local corruption is contagious, since for each corrupt neighboring municipality there is an increased probability of being "infected" with corruption as well as the likelihood of being accused.

\section{Relationship between corruption and tax revenues at the municipal level}

According to Transparency International (2010), the relation between corruption and tax revenues is uncertain and deserves greater attention and it recommends that more empirical research be carried out to deepen this understanding. Additionally, research has found that corruption increases spending (Liu \& Mikesell, 2014). Therefore, it is not unreasonable to expect that corruption will raise tax revenues. Higher tax revenues provide more spoils for distribution.

So the questions we are trying to answer in this paper are: Does corruption have a significant impact on municipal tax revenues? Is it likely that a public administration with a higher level of corruption will have a higher level of tax revenues?

\subsection{Sample and variables}

The sample is made up of a data panel of all Spanish municipalities with a population of over 50,000 inhabitants (except those in the Basque Country and Navarre, for which no data are available) for the period 2002-2013. This period of time is similar to other studies on corruption that also use panel data (Hessami, 2014; Liu \& Mikesell, 2014).
Bearing in mind that we have both cross-sectional and temporal information, we will also use this panel data model to estimate the parameters we consider of interest.

As mentioned, our aim is to analyze the impact of corruption on public revenues at the local level. Therefore, as a dependent variable, we consider own tax revenues in per capita terms (revenuespc).

Since there is no official indicator of corruption at the local level in Spain, we have used information from news of political scandals that have appeared in the digital media. Thus, a database has been compiled (for municipalities with more than 50,000 inhabitants during the period 2002-2013), where it is recorded whether the mayor is or not formally charged with corruption during the electoral term, regardless of the type of corruption (bribery, influence peddling, embezzlement, gifts, etc.). This information does not capture the extent of corruption fully and perfectly, but, in our opinion, and in the absence of precise information on the conviction or otherwise of the persons under investigation, it provides a reliable, relevant and valid criterion. Furthermore, justice in Spain is very slow and there are probably many cases awaiting a verdict.

Our way of measuring corruption is different from other measures that have been used, such as the corruption perception index or the number of news items generated by a given scandal. These two ways of proceeding have the advantage of providing a measurable data, but it is still true that they are subject to manipulation. For example, a newspaper that wants to cause harm to a certain politician can significantly increase the number of news items related to the corruption of that politician. In the same manner, if it benefits him, the number of news can be reduced.

Information on the elections of 1999, 2003, 2007 and 2011 has been taken into account. From this database, the variable Corruption has been elaborated, which takes the value of 1 every year that an accused mayor has governed, and 0 if not. The use of data in the press on local corruption scandals in Spain, as an approximation to local corruption cases, has also been used by Villoria \& Jiménez (2012), Jiménez (2013) and Benito et al. (2015). Some of the studies that relate corruption and revenues determine an inverse relationship between both variables (Hwang, 2002; Ghura, 2002) but when different types of taxes are distinguished they obtain a positive, negative or non-significant association (Ghura, 2002, Imam \& Jacobs, 2007).

Besides corruption, other variables have been identified that may influence the per capita revenues of each municipality:

- Per capita transfers: these are expected to have a negative effect on revenues, since an increase in the transfers received may allow municipal managers to reduce the tax burden without reducing the total level of revenues (Vicente, 2010; Canavire-Bacarreza \& Zúñiga-Espinoza, 2015; Valenzuela-Reynaga \& Hinojosa-Cruz, 2017).

- Income is an indicator of consumer purchasing power. It is taken from the La Caixa Yearbooks, and 10 levels, from 1 to 10, are defined (Benito \& Bastida, 2008, and Benito et al., 2015) use this variable to represent the economic level). It is considered that the relationship between economic level and tax revenues level should be positive, so, in principle, the richest municipalities will have higher levels of tax revenues. However, although there are works in which a positive relationship is obtained (Benito \& Bastida, 2008), in others it is negative (Benito et al., 2010). 
Table 2

Variables used

\begin{tabular}{|c|c|c|c|}
\hline Name & Definition & Source & $\begin{array}{l}\text { Expected } \\
\text { sign }\end{array}$ \\
\hline Revenuespc & $\begin{array}{l}\text { Real revenues (base 2002) per } \\
\text { capita corresponding to own taxes }\end{array}$ & $\begin{array}{l}\text { Ministry of } \\
\text { Finance }\end{array}$ & Positive \\
\hline Corruption & $\begin{array}{l}\text { Dummy variable that takes the } \\
\text { value } 1 \text { for all the years of the } \\
\text { mayorś mandate and the value } 0 \text { for } \\
\text { the remaining years }\end{array}$ & $\begin{array}{c}\text { Own } \\
\text { elaboration }\end{array}$ & $?$ \\
\hline Transferspc & $\begin{array}{l}\text { Real transfers (base 2002) received } \\
\text { per capita }\end{array}$ & $\begin{array}{l}\text { Ministry of } \\
\text { Finance }\end{array}$ & $?$ \\
\hline Income & $\begin{array}{l}\text { Income of the municipality. } \\
\text { Variable that takes values from } 1 \\
\text { (lower income) to } 10 \text { (higher } \\
\text { income) }\end{array}$ & $\begin{array}{l}\text { Anuario La } \\
\text { Caixa - } \\
\text { Instituto } \\
\text { Klein }\end{array}$ & $?$ \\
\hline LnPop & $\begin{array}{c}\text { Population of the municipality in } \\
\text { Neperian logarithm }\end{array}$ & $\begin{array}{l}\text { National } \\
\text { Institute of } \\
\text { Statistics }\end{array}$ & Positive \\
\hline Pop_18_64 & $\begin{array}{c}\text { Percentage of population between } \\
18 \text { and } 64 \text { years of age in relation to } \\
\text { the total population }\end{array}$ & $\begin{array}{l}\text { National } \\
\text { Institute of } \\
\text { Statistics }\end{array}$ & Positive \\
\hline Majority & $\begin{array}{l}\text { Political strength } \\
\text { Dummy variable that takes the value } \\
\text { of } 1 \text { if the ruling party has a majority } \\
\text { and } 0 \text { if it does so in coalition. }\end{array}$ & $\begin{array}{l}\text { Ministry of } \\
\text { the Interior }\end{array}$ & $?$ \\
\hline Ideology & $\begin{array}{c}\text { Political ideology } \\
\text { Variable dummy that takes the value } \\
1 \text { if the governing party is right-wing } \\
\text { and } 0 \text { if left-wing }\end{array}$ & $\begin{array}{l}\text { Ministry of } \\
\text { the Interior } \\
\text { and } \\
\text { municipal } \\
\text { websites }\end{array}$ & $?$ \\
\hline Year_elect & $\begin{array}{l}\text { Dummy variable that takes the } \\
\text { value of } 1 \text { if it is an election year } \\
\text { and } 0 \text { if not }\end{array}$ & $\begin{array}{l}\text { Own } \\
\text { elaboration }\end{array}$ & Negative \\
\hline Pre_Year_elect & $\begin{array}{c}\text { Dummy variable that takes the } \\
\text { value of } 1 \text { if it is the year before the } \\
\text { elections and } 0 \text { if not }\end{array}$ & $\begin{array}{c}\text { Own } \\
\text { elaboration }\end{array}$ & $?$ \\
\hline Post_Year_elect & $\begin{array}{l}\text { Dummy variable that takes the } \\
\text { value of } 1 \text { if it is the year after the } \\
\text { elections and } 0 \text { if it is not }\end{array}$ & $\begin{array}{l}\text { Own } \\
\text { elaboration }\end{array}$ & $?$ \\
\hline ComAuto_X & $\begin{array}{l}\text { Dummy variable for each } \\
\text { Autonomous Community (region) } \\
\text { that takes value } 1 \text { if the municipality } \\
\text { belongs to the Autonomous } \\
\text { Community and } 0 \text { if not } \\
X=1 \text { to } 16\end{array}$ & $\begin{array}{c}\text { Own } \\
\text { elaboration }\end{array}$ & $?$ \\
\hline
\end{tabular}

- The population of the municipality in order to monitor the possible existence of economies of scale. However, previous literature has shown that municipalities with larger populations have higher per capita tax revenues (Mauro, 1995; Goel \& Nelson, 2011; Larmour \& Wolanin, 2013; Liu \& Mikesell, 2014; Liu \& Mikesell, 2019).

- The proportion of the population between 18 and 64 years of age that can be considered as a control variable whose expected sign according to the literature is positive (Mauro, 1998; Liu \& Mikesell, 2014).

- The ideology of the ruling party and political strength, as political characteristics that explain revenues. Their impact in the literature is not very clear. Solé-Ollé (2006) indicates that for left wing governments, taxes increase when the margin in votes is higher, while for right wing governments, an increase in the margin of victory leads to reduction in taxes. However, Benito \& Bastida (2008) conclude that political ideology has no clear influence. Allers et al. (2001) show that majority governments have lower tax levels, and Benito et al. (2010) report that strong governments increase the tax burden to finance their political projects.
- The region where the municipality is located (Goel \& Nelson, 2011; Hessami, 2014; Moldogaziev et al., 2017).

- The electoral cycle (electoral year, pre-election year and post-election year (Gonçalvez \& Veiga, 2007; Benito et al., 2010). Taxes are expected to decrease in election years.

Tables 2, 3a and 3b show the description of the variables used, the descriptive statistics of the quantitative variables and the dummy variables, respectively.

Table 3a

Main descriptive measures of the quantitative variables

\begin{tabular}{lrrrr}
\hline Variable & Mean & $\begin{array}{r}\text { Standard } \\
\text { deviation }\end{array}$ & Minimum & Maximum \\
\hline Revenuespc & 566,77 & 196,79 & 180,71 & $1.432,88$ \\
Transferspc & 279,98 & 96,01 & 70,374 & 724,47 \\
Income & 6,26 & 2,10 & 2,00 & 10,00 \\
LnPop & 11,59 & 0,74 & 10,43 & 15,00 \\
Pop_18_64 & 64,77 & 2,77 & 55,07 & 74,07 \\
\hline
\end{tabular}

Table 3b

Main descriptive measures of dummy variables

\begin{tabular}{lrrr}
\hline Measures/Variable & Corruption $=1$ & Ideology $=1$ & Majority $=1$ \\
\hline Frequency & 243,00 & 875,00 & 948,00 \\
Percentage & 14,89 & 53,62 & 58,09 \\
\hline
\end{tabular}

\subsection{Model}

Research on corruption must address problems of endogeneity and reverse causality (Mauro, 1998). In the literature, corruption and institutional variables are generally considered endogenous (Mauro, 1995; Acemoglu et al., 2001; Dreher \& Schneider, 2010) since they may affect revenues, but they may also help to improve institutions and thus reduce corruption. Therefore, we use the Generalized Method of Moments (GMM), as in the Iman \& Jacobs (2007), Hessami (2014) and Liu \& Mikesell (2014). One fundamental reference in this context is the work of Arellano \& Bond (1991).

The econometric model that explains the impact of corruption on municipal tax revenues is given by

$$
\begin{aligned}
\text { Revenuespc }_{i t}= & \alpha_{0}+\alpha_{1} \text { Revenuespc }_{i(t-1)}+\alpha_{2} \text { Corruption }_{i t} \\
& +\sum_{j} \beta_{j} x_{j i t}+\mu_{i}+v_{i t}
\end{aligned}
$$

where sub-indices $\mathrm{i}$ and $\mathrm{t}$ denote the municipality (from 1 to 145) and the year (from 2002 to 2013), respectively. The delayed-dependent variable (Revenuesp $c_{i(t-1)}$ ) is included as a regressive variable because budget figures usually follow an incremental approach, and this budgetary inertia needs to be controlled (Dezhbakhsh et al., 2003). In addition to corruption, all other explanatory variables are represented in $x_{j i t}$. To control for fixed municipal effects (unobserved heterogeneity), we have $\mu_{i}$, with $v_{i t}$ being the error term. We are mainly interested in knowing the sign of coefficient $\alpha_{2}$ and whether it is significant.

Taking into account the set of variables discussed above, the specification of the panel data model is 
Revenuespc $=f$ (Revenuespcf romdepreviousyear;

Corruption; Transferspc; Income;

LnPop; Pop_18_64;Majority;Ideology;

Year_elect;Pre_Year_elect;

Post_Year_elect;dummyregionals)

Before estimating the model, it is advisable to make an analysis of correlations between the variables in order to exclude those that have a high correlation. Although there is no exact criterion for which correlation we should consider for the elimination of a variable, it is estimated that it should be less than or equal to 0.7 . In our case the biggest correlation is equal to 0.4309 , so we will enter all the variables.

\subsection{Results}

In order to make an estimate using GMM, it is necessary to check beforehand that certain requirements are met. First, it must be proven that endogeneity has been adequately addressed in the model using the Arellano-Bond autocorrelation test. For the estimate to be valid, the error terms can be $\mathrm{AR}(1)$, i.e. they can be correlated over a period of time, but they must not follow an AR(2) process.

Table 4 shows that there is no second-order autocorrelation in terms of conventional significance levels. In addition, the aggregate validity of all instruments used must be verified, using Hansen's over-identification of restrictions test. Roodman (2009) advises imposing a minimum p-value of 0.25 in this test, instead of the usual 0.05 , as a limit in order not to reject the null hypothesis. Since the p-value obtained is equal to 0.458 , we confirm the absence of correlation between the instruments and the error term. Care must be taken to avoid a critical value close to 1 , which does not mean that the instruments are valid, but rather that the properties of the test are probably not being met, in which case we must reject the null hypothesis.

The Harris-Tzavalis test (Harris \& Tzavalis, 1999) tests the null hypothesis that the data contain a unitary root against the alternative that the series is stationary. When we obtain a statistic value of 0.5088 with a p-value of 0.0000 , we can consider that the series is stationary. In summary, the model in Table 4 satisfies all the requirements of valid estimators of a GMM model in terms of autocorrelation, over-identification and exogeneity of the instruments.

First, as can be seen (Table 4), the coefficient of the delayed dependent variable (the tax revenues of the previous year, Revenuesp $\left.c_{i(t-1)}\right)$ is significant and positive, which indicates that municipal tax revenues in a given year are largely explained by those of the previous year. Therefore, there is evidence of inertia in the evolution of tax revenues in municipalities, a result that coincides with those obtained in various works, e.g., Vicente (2010).

The corruption variable is one of the statistically significant determinants (with a positive sign) of municipal income at 5\%. Thus, municipalities with higher levels of corruption have higher tax revenues in per capita terms. One possible explanation for this result is that since the more corrupt municipalities have higher public spending (empirically obtained from the previous literature we discussed in section 4), they also need higher revenues to finance that spending, as Allers et al. (2001) indicate. Liu \& Mikesell (2019) also find a significantly positive association between corruption and tax revenues. They conclude that a state with greater corruption is likely to have a more complex tax system and the fiscal illusion that results allows a government to collect larger tax revenues.

Table 4

Impact of corruption on municipal tax revenues, 2002-2013

\begin{tabular}{|c|c|c|c|}
\hline Variable & Coefficient & Statistical z & p-value \\
\hline Revenuespc $_{t-1}$ & **** 0,7664 & 11,92 & 0,000 \\
\hline Corruption & ** 35,8039 & 1,97 & 0,039 \\
\hline Transferspc & ** $-0,1059$ & $-2,52$ & 0,012 \\
\hline Income & ** 7,4597 & 2,25 & 0,024 \\
\hline LnPop & $-14,3581$ & $-0,95$ & 0,344 \\
\hline Pop_18_64 & 0,7114 & 0,40 & 0,689 \\
\hline Majority & $-3,2413$ & $-0,52$ & 0,602 \\
\hline Ideology & $* * *-36,8688$ & $-4,06$ & 0,000 \\
\hline Year_elect & *** $-18,7308$ & $-3,40$ & 0,001 \\
\hline Pre_Year_elect & $-8,0349$ & $-1,17$ & 0,242 \\
\hline Post_Year_elect & $*-13,2293$ & $-1,69$ & 0,091 \\
\hline Constant & 203,086 & 0,99 & 0,324 \\
\hline$H_{0}: A R(1)$ (p-value) & $-3,63(0,0001)$ & & \\
\hline$H_{0}: A R(2)(p$-value $)$ & $0,84(0,398)$ & & \\
\hline Hansen test (p-value) & $127,01(0,458)$ & & \\
\hline Panel Data & Harris-Tzavalis & & \\
\hline Single root test & $0,5088(0,000)$ & & \\
\hline
\end{tabular}

Significant $* 10 \%, * * 5 \%, * * * 1 \%$

Regional dummy variables are not included

Transfers (with a negative sign) also have an influence, as in the studies of Canavire-Bacarreza \& Zúniga-Espinoza (2015) and Valenzuela-Reynaga \& Hinojosa-Cruz (2017). The higher the transfers received, the lower the revenues required to cover the needs of the municipality.

The municipality's income has a significant and positive effect on revenues. The municipalities with the highest economic level have a higher level of tax revenues, as is shown by Allers et al. (2001) and Benito \& Bastida (2008).

Population variables are not significant, as in Benito et al. (2010). The same occurs with the political strength represented by the presence of a majority in local government. This result is contrary to that referenced in Allers et al. (2001) and Hagen \& Vabo (2005), where the strength of the party in power meant lower revenues, and to that of Benito et al. (2010), who found a positive relationship. However, it does coincide with Lago-Peñas (2004) and Borge (2005).

The political ideology of the governing party is another determining factor (with a negative sign) of tax revenues. Right-wing municipal governments have a lower level of tax revenues than municipalities governed by left-wing parties, a result that coincides with Allers et al. (2001) and Borge (1995), but differs from that reported by Benito et al. (2010), since their data do not allow us to conclude that the political sign of the government influences the tax burden of the municipality.

Being an electoral year is also a determining factor (with a negative sign) in the level of tax revenues and, at $10 \%$, the year following the celebration of municipal elections (with a negative sign) is also significant, but the previous year is not. In election years local politicians tend to reduce taxes, showing their clearly electoralist intention. This result coincides with Gonçalvez \& Veiga (2007) and Benito et al. (2010) but differs from the conclusions of Lago-Peñas (2004).

\section{Conclusions and further research}

Many studies relate corruption to government spending, showing that the most corrupt countries have higher levels 
of spending, but there are very few studies dealing with corruption in relation to revenues, and these are at the country level.

Moreover, in most of the research, the measurement of corruption is based on opinion surveys, which means they are subjective, while our corruption measure (based on imputations of mayors) provides a more objective view.

The main aim of this paper was to analyze how the level of corruption can affect tax revenues at the municipal level, taking into account the political characteristics of governments. To this aim, we selected the Spanish municipalities with more than 50,000 inhabitants and the time period 2002-2013. During this period, three municipal elections were held, which in some cases resulted in changes in the political sign of the government or changes in the mayor, even when he or she belonged to the same party. In order to study the relationship between revenues and corruption, it is necessary to use instrumental variable methods to control the endogeneity potential between the variables, and here we use the GMM method.

A statistically significant relationship has been found with per capita transfers. The higher the value of the transfers received, the lower the own revenues required to cover the needs of the municipality. Empirical evidence has also been obtained that shows that the higher the economic level, the higher the tax revenues.

In addition, the political sign of the government influences its tax revenues; however, we do not obtain evidence that political strength or population does.

We have also observed that in the election year there is a lower level of revenue, compared to the rest of the years of the legislature (it lasts four years). The tax burden decreases, which confirms that local governments use the budget opportunistically to maximize their chances of being re-elected.

An important issue that we could address in a later analysis is the relationship between revenue and corruption according to the type of tax, because corruption may affect it differently. The effect of the political sign of the central or regional government could also be analyzed, since the municipalities politically related to the central and regional governments may act differently.

Transparency laws have become a measure, even the main measure, against corruption and thus a mechanism for regaining the confidence of citizens. Therefore, another line of action would be to check the effect of this variable on corruption and revenues, since the existence of a law in itself does not necessarily imply that corruption is reduced, but that an ethical attitude and a desire to put an end to corruption exist.

Finally, since corruption influences municipal revenues and expenditures, another line of work would be to analyze the relationship between corruption and municipal debt.

\section{Funding}

This research did not receive any specific grant from funding agencies in the public, commercial or not-for-profit sectors.

\section{Conflict of interests}

The authors declare no conflict of interests.

\section{References}

Acemoglu, D., Johnson, S., \& Robinson, J. (2001). The colonial origins of comparative development: An empirical investigation. American Economic Review, 91, 1369-1401. https://doi.org/10.1257/aer.91.5.1369

Ades, A., \& Di Tella, R. (1999). Competition and Corruption. American Economic Review, 89(4), 982-993. https://doi. org/10.1257/aer.89.4.982

Jiménez, J.L., \& Albalate, D. (2018). Transparency and corruption: what does lack of transparency hide? European Journal of Government and Economics, 7(2), 106-122. https://doi.org/10.17979/ejge.2018.7.2.4509

Alcaide Zugaza, L., \& Larrú Ramos, J.M. (2007). Corrupción, ayuda al desarrollo, pobreza y desarrollo humano. Boletín económico de ICE, 2917, 37-58. Available at url\{https://repositorioinstitucional.ceu.es/ bitstream/10637/1341/1/Corrupcion_Alcaide\&Larru_ CuadEconICE 2009.pdf\}

Allers, M., De Haan, J., \& Sterks, C. (2001). Partisan influence on the local tax burden in the Netherlands. Public Choice, 106(3-4), 351-363. https://doi.org/10.1023/A: 1005123208352

Apergis, E., \& Apergis, N. (2017). US political corruption: Identifying the channels of bribes for firms' financial policies. International Review of Financial Analysis, 54(6), 87-94. https://doi.org/10.1016/j.irfa.2017.09.010

Arellano, M., \& Bond, S. (1991).Some tests of specification for panel data: Monte Carlo evidence and an application to employment equations. Review of Economic Studies, 58(2), 277-297. https://doi.org/10.2307/2297968

Ashworth, J., Geys, B., \& Heyndels, B. (2005). Government weakness and local public debt development in Flemish municipalities. International Tax and Public Finance, 12(4), 395-422. https://doi.org/10.1007/ s10797-005-2317-3

Atta-Mensah, J. (2016). The valuation of corruption. Journal of Mathematical Finance, 6, 728-746. https://doi.org/10. 4236/jmf.2016.65051

Báez Gómez, J.E. (2013). Relación entre el índice de control de la corrupción y algunas variables sociales, económicas e institucionales. Nómadas. Revista Crítica de Ciencias Sociales y Jurídicas, 38(2). Available at https://webs.ucm. es/info/nomadas/38/jebaezgomez.pdf

Benito, B., \& Bastida, F. (2008). Política y gestión financiera municipal. Revista de contabilidad-Spanish Accounting Review, 11(2), 43-66. Available at https://revistas.um.es/ rcsar/article/view/382781

Benito, B., Bastida, F., \& Muñoz, M.J. (2010). Factores explicativos de la presión fiscal municipal. Revista de Contabilidad-Spanish Accounting Review, 13(2), 239-283. https://doi.org/10.1016/S1138-4891(10)70018-2

Benito, B., Bastida, F., Guillamón, M.D., \& Ríos, A. (2018). Analysis of corruption and electoral outcomes in Spanish local governments. Working paper, Universidad de Murcia: España.

Benito, B., Guillamón, M.D., \& Bastida, F. (2015). Determinants of urban political corruption in local governments. Crime, Law and Social Change, 63, 191-210. https://doi. org/10.1007/s10611-015-9563-9

Benito, B., Guillamón, M.D., Ríos, A., \& Bastida, F. (2018). Can salaries and re-election prevent political corruption? An empirical evidence. Revista de Contabilidad-Spanish Accounting Review 21, (1), 19-27. https://doi.org/10. 1016/j.rcsar.2017.04.003

Bhattacharyya, S., \& Hodler, R. (2010). Natural resources, 
democracy and corruption. European Economic Review, 54, 4, 608-621. https://doi.org/10.1016/j.euroecorev. 2009.10.004

Boehm, F. (2015). Democracy and corruption. Dimensión Empresarial, 13(2), 75-85. https://doi.org/10.15665/ rde.v13i2.558

Borge, L. (1995). Economic and political determinants of fee income in Norwegian local governments. Public Choice, 83(3), 353-373. https://doi.org/10.1007/BF01047752

Borge, L. (2005). Strong politicians, small deficits: evidence from Norwegian local governments. European Journal of Political Economy, 21(2), 325-344. https://doi.org/10. 1016/j.ejpoleco.2004.06.005

Brodschi, E., Fracchia, E., \& López Amorós, M. (2008). Corrupción y desarrollo: Una revisión crítica de la literatura reciente. Available at http: //www.iae.edu.ar/pi/Documentos\%20Investigacin/ Research\%20Seminars/Corrupcion.pdf

Canavire-Bacarreza, G., \& Zúñiga-Espinoza, N.G. (2015). Transferencias e impuesto predial en México Fiscal Transfers and PropertyTax in Mexico. Economía UNAM, 12 (35), 69-99. https://doi.org/10.4236/me.2018.91005

Castañeda Rodríguez, V.M. (2016). Una investigación sobre la corrupción pública y sus determinantes. Revista Mexicana de Ciencias Políticas y Sociales, LXI, núm. 227, 103136. Available at https://www.redalyc.org/pdf/421/ 42146505004.pdf

Castillo, A. (2003). Medición de la corrupción: Un indicador de la Rendición de Cuentas. Serie: Cultura de la Rendición de Cuentas, Auditoría Superior de la Federación, Méjico. Available at url\{https://www.asf.gob.mx/ uploads/63 Serie de Rendicion de Cuentas/Rc5.pdf\}

Cerqueti, R., \& Coppier, R. (2011). Economic growth, corruption and tax evasion. Economic Modelling, 28(1), 489500. https://doi.org/10.1016/j.econmod.2010.07.006

Chacón, F., \& Sauma, P. (2016). Índices de Democracia, Corrupción y Paz. Proyecto de investigación en "Indicadores internacionales de desarrollo: seguimiento e interpretación para Costa Rica", Serie Indicadores internacionales de desarrollo $N \check{r}$ 8, Observatorio del Desarrollo, Universidad de Costa Rica. Available at url\{http://odd.ucr.ac.cr/sites/default/files/indicadores internacionales de desarrollo/2015/application/pdf/ Serie IID 08 IDCP.p.pdf

Christos, P., Eleni, K., Dimitrios, K., Zacharias, D., Athanasios, A., \& Panagiotis, L. (2018). Corruption Perception Index (CPI), as an Index of Economic Growth for European Countries. Theoretical Economics Letters, 8, 524-537. https://doi.org/10.4236/tel.2018.83037

Dezhbakhsh, H., Rubin, P.H., \& Shepherd, J.M. (2003). Does capital punishment have a deterrent effect? New evidence from post-moratorium panel data. American Law and Economics Review, 5(2), 344-376. https://doi.org/ 10.1093/aler/ahg021

Dimant, E., \& Tosato, G. (2018). Causes and effects of corruption: what has past decade's empirical research taught us? A survey. Journal of Economic Surveys, 32(2), 335356. https://doi.org/10.13140/RG.2.1.4784.0888

Djankov, S., La Porta, R., Lopez-de-SilanesDjankov, F., \& ShleiferDjankov, A. (2002). The regulation of entry. The Quarterly Journal of Economics, 117(1), 1-37. https:// doi.org/10.1162/003355302753399436

Dreher, A., \& Herzfeld, T. (2005). The Economic Costs of Corruption: A Survey and New Evidence. Working Paper 0506001, Public Economics, EconWPA. Available at https://econwpa.ub.uni-muenchen.de/econ-wp/ pe/papers/0506/0506001.pdf

Dreher, A., \& Schneider, F. (2010). Corruption and the Shadow Economy: An Empirical Analysis. Public Choice, 144 (1-2), 215-238. https://doi.org/10.1007/ s11127-009-9513-0

Dreher, A., Kotsogiannis, C., \& McCorriston, S. (2009). How do Institutions Affect Corruption and the Shadow Economy? International Tax and Public Finance, 16(6), 779796. https://doi.org/10.1007/s10797-008-9089-5

Enste, D., \& Heldman, C. (2017). Causes and consequences of corruption: An overview of empirical results. IWReport, 2/2017, Institut der deutschenWirtschaft (IW), Köln. Available at https://www.econstor.eu/bitstream/ 10419/157204/1/IW-Report-2017-02.pdf

Ferraz, C., \& Finan, F. (2008). Exposing corrupt politicians: the effects of Brazil's publicly released audits on electoral outcomes. The Quarterly Journal of Economics, 123(2), 703-745. https://doi.org/10.1162/qjec.2008.123.2.703

Ferraz, C., \& Finan, F. (2011). Electoral Accountability and Corruption: Evidence from the Audits of Local Governments. American Economic Review, 101(4), 1274-1311. https://doi.org/10.1257/aer.101.4.1274

Freille, S., Haque, E.M., \& Kneller, R. (2007). A Contribution to the Empirics of Press Freedom and Corruption. European Journal of Political Economy, 23(4), 838-862. https://doi.org/10.1016/j.ejpoleco.2007.03.002

Gächter, S., \& Schulz, J.F. (2016). Intrinsic honesty and the prevalence of rule violations across societies. Nature, 531, 496-499. https://doi.org/10.1038/nature17160

Gerring, J., \& Thacker, S. (2005). Do Neoliberal Policies Deter Political Corruption? International Organization, 59(1), 233-254. https://doi.org/10.1017/ S0020818305050083

Ghura, D. (2002). Tax Revenue in Sub-Saharan Africa: Effects of economic policies and corruption. In: Governance, Corruption \& Economic Performance. Abed, G., \& S. Gupta (eds.). Washington, D.C.: International Monetary Fund (IMF), 369-395.

Goel, R.K., \& Nelson, M.A. (2011). Measures of corruption and determinants of US corruption. Economics of Governance, 12(2), 155-176. https://doi.org/10.1007/ s10101-010-0091-X

Golden, M., \& Picci, L. (2005). Proposal for a new measure of corruption, illustrated with Italian data. Economics and Politics, 17, 37-75. https://doi.org/10.1111/j. 1468-0343.2005.00146.x

Gonçalvez, L., \& Veiga, F.J. (2007). Political business cycles at the municipal level. Public Choice, 131 (1-2), 45-64. https://doi.org/10.1007/s11127-006-9104-2

Gupta, S., Davoodi, H., \& Alonso-Terme, R. (2002). Does corruption affect income inequality and poverty? Economic of Governance, 3, 23-45. https://doi.org/10.1007/ s101010100039

Hagen, T.P., \& Vabo, S.I. (2005). Political characteristics, institutional procedures and fiscal performance: Panel data analyses of Norwegian local governments, 1991- 1998. European Journal of Political Research, 44, 43-64. https: //doi.org/10.1111/j.1475-6765.2005.00218.x

Harris, R.D.F., \& Tzavalis, E. (1999). Inference for unit roots in dynamic panels where the time dimension is fixed. Journal of Econometrics, 91, 201-226. https://doi.org/ 10.1016/S0304-4076(98)00076-1

Hawthorne, O. (2013). Transparency International's Corruption Perceptions Index: 'best flawed' measure on Corruption? Mona, Jamaica: Department of Government, Uni- 
versity of the West Indies.

Hessami, Z. (2014). Political corruption, public procurement, and budget composition: Theory and evidence from OECD countries. European Journal of Political Economy, 34, 372-389. https://doi.org/10.1016/j.ejpoleco. 2014.02 .005

Huang, C.J. (2016). Is corruption bad for economic growth? Evidence from Asia-Pacific countries. The North American Journal of Economics and Finance, 35, 247-256. https:// doi.org/10.1016/j.najef.2015.10.013

Hwang, J. (2002). A note on the relationship between corruption and government revenue. Journal of Economic Development 161, 27(2), 161-178. Available at http:// www.jed.or.kr/full-text/27-2/hwang.PDF

Imam, P. A., \& Jacobs, D. J. (2007). Effect of corruption on tax revenues in the Middle East. IMF Working Paper. Available at https://www.imf.org/external/pubs/ft/wp/ 2007/wp07270.pdf

IMF (2016). Corruption: costs and mitigating strategies. International Monetary Fund. Available at https://www.imf. org/external/pubs/ft/sdn/2016/sdn1605.pdf

Jiménez, F., \& Villoria, M. (2008). Percepción social de la corrupción en España, Anuario de la Facultad de Derecho de la Universidad Autónoma de Madrid (afduam) 12, 169. 183.

Jiménez, J. L., \& García, C. (2012). Corruption and local politics: Does it pay to be a crook? IREA working paper, 2012/12. Available at http:/ / www.ub.edu/ubeconomics/wp-content/uploads/ 2013/01/201212.pdf

Jiménez, J.L. (2013): Corrupción local en España, Cuadernos económicos de ICE, nž 85, 23-41.

Jiménez, J. L., \& García, C. (2016). Does local public corruption generate partisan effects on polls? Crime, Law and Social Change, 65, 1-21. https://doi.org/10.1007/ s10611-016-9671-1

Johnson, S., Kaufmann, D., \& Zoido-Lobaton P. (1998). Corruption, Public Finances and the Unofficial Economy. World Bank Policy Research Working Paper Series, No. 2169.The World Bank, Washington, D.C. https://doi. org/10.1596/1813-9450-2169

Kargbo, A. H. (2006). Corruption: Definition and concept manifestations and typology in the African context. Presented in The Training for Members of parliament and Civil Society from English Speaking West Africa, Aberdeen.

Kaufmann, D., and Kraay, A. (2016). Worldwide Governance Indicators, http://info.worldbank.org/governance/wgi/ index.aspx/\#home \19.7.2018.

Knack, S., \& Azfar, O. (2003). Trade Intensity, Country Size and Corruption, in: Economics of Governance, 4, 1, 1-18. https://doi.org/10.1007/s101010200051

Kunicova, J., \& Rose-Ackerman, S. (2005). Electoral Rules and Constitutional Structures as Constraints on Corruption. British Journal of Political Science, 35 (4), 573-606. https://doi.org/10.1017/S0007123405000311

Lago-Peñas, S. (2004). Local governments' asymmetric reactions to grants: looking for the reasons. Papeles de trabajo del Instituto de Estudios Fiscales, Serie Economía, nž 22. Available at url\{https://www.ief.es/docs/destacados/ publicaciones/papeles trabajo/2004_22.pdf $\}$

Lambsdorff, J.G. (2006). Causes and Consequences of Corruption: What Do We Know from a Cross-Section of Countries?. In International Handbook on the Economics of Corruption. London: Edward Elgar, 3-51. https: //doi.org/10.4337/9781847203106.00007

LaPalombara, J. (1994). Structural and Institutional Aspects of Corruption. Social Research, LXI, 325-350. https:// www.jstor.org/stable/i40043686

Larmour, P., \& Wolanin, N. (2013). Corruption and AntiCorruption. Canberra: The Australian National University Press. http://dx.doi.org/10.22459/CAC.03.2013

Lederman, D., Loayza, N.V., \& Soares, R. (2005). Accountability and Corruption. Political Institutions Matter Economics and Politics, 17(1), 1-35. https://doi.org/10.1111/j. 1468-0343.2005.00145.X

Leff, N.H. (1964). Economic Development through Bureaucratic Corruption. American Behavioral Scientist, 8(3), 814. https://doi.org/10.1177/000276426400800303

Liu, J., \& Lin, B. (2012). Government auditing and corruption control: Evidence from China's provincial panel data. China Journal of Accounting Research, 5(2), 163186. https://doi.org/10.1016/j.cjar.2012.01.002

Liu, C., \& Mikesell, J.L. (2014). The impact of public officials' corruption on the size and allocation of U.S. state spending. Public Administration Review, 74(3), 346-359. https://doi.org/10.1111/puar.12212

Liu, C., \& Mikesell, J.L. (2019). Corruption and Tax Structure in American States. American Review of Public Administration, 49(5), 585-600. https://doi.org/10.1177/ 0275074018783067

López-Valcárcel, B.G., Jiménez, J.L., \& Perdiguero, J. (2017). Danger: Local corruption is contagious! Journal of Policy Modeling, 39(5), 790-808. https://doi.org/10.1016/j. jpolmod.2017.08.002

Lui, F.T. (1985). An Equilibrium Queuing Model of Bribery. Journal of Political Economy, 93, 4, 760-781. http://dx. doi.org/10.1086/261329

Matsheza, P. (2007). Corruption: Concepts and Definition. UNODUC, Anti-Corrupt Unit, Specialized Training Workshop for Investigators and Prosecutors on Corruption made from 5th to 9th of March 2007, Kenya.

Mauro, P. (1995). Corruption and growth. The Quarterly Journal of Economics, 110(3), 681-712. https://doi.org/ $10.2307 / 2946696$

Mauro, P. (1996). The Effects of Corruption on Growth, Investment, and Government Expenditure. IMF Working Paper, 1-28. Available at file:///C:/Users/USUARIO/ Downloads/SSRN-id882994.pdf

Mauro, P. (1998). Corruption and the composition of government expenditure. Journal of Public Economics, 69(2), 263-279. Available at url\{http://darp.lse.ac.uk/ PapersDB/Mauro (JPubE 98).pdf\}

Mocan, N. (2008). What determines corruption? International evidence from microdata. Economic Inquiry, 46(4), 493-510. https://doi.org/10.3386/w10460

Moldogaziev, T.T., Liu, C., \& Luby, M.J. (2017). Public corruption in the U.S. States and its impact on public debt pricing. Kyklos, 70(2), 161-343. https://doi.org/10.1111/ kykl.12139

Mynt, U. (2000). Corruption: causes, consequences and cures. Asia-Pacific Development Journal, 7(2), 33-58.

Paldam, M. (2001). Corruption and religion. Adding to the economic model. Kyklos, 54(2/3), 383-414. https://doi. org/10.1111/1467-6435.00160

Pellegrini, L., \& Gerlagh, R. (2008). Causes of corruption: A survey of cross-country analyses and extended results. Economics of Governance, 9, 245-263. https://doi.org/ 10.1007/s10101-007-0033-4

Pettersson-Lidbom, P. (2001). An empirical investigation of the strategic use of debt. The Journal of Political Economy, 
109(3), 570-583. http://dx.doi.org/10.1086/321021

Rock, M.T. (2009). Corruption and Democracy. Journal of Development Studies, 45(1), 55-75. https://doi.org/10. $1080 / 00220380802468579$

Roodman, D. (2009). A note on the theme of too many instruments. Oxford Bulletin of Economics and Statistics, 71(1), 135-158. https://doi.org/10.1111/j.1468-0084. 2008.00542.x

Saha, S., Gounder, R., \& Su, J. J. (2009). The interaction effect of economic freedom and democracy on corruption: A Panel cross-country analysis. Economic Letters, 105(2), 173-176. https://doi.org/10.1016/j. econlet.2009.07.010

Salinas Jiménez, M.M., \& Salinas Jiménez, J. (2007). Corrupción y actividad económica: una visión panorámica. Hacienda Pública Española, Revista de Economía Pública, 180, 109-137.

Sanyal, A., Gang, I., \& Goswami, O. (2000). Corruption, tax evasion and the Laffer curve. Public Choice, 105(1-2), 6178. https://doi.org/10.1023/A:1005105822911

Shabbir, G., \& Anwar, M. (2007). Determinants of Corruption in Developing Countries. The Pakistan Development Review, 46(4), 751-764. https://doi.org/10.30541/ v46i4IIpp.751-764

Soto, R. (2003). La corrupción desde una perspectiva económica. Estudios Públicos, 89, 23-62.

Solé-Ollé, A. (2006). The effects of party competition on budget outcomes: Empirical evidence from local governments in Spain. Public Choice, 126(1-2), 145-176.

Sung, H-E.and Chu, D. (2003). Does Participation in the Global Economy Reduce Political Corruption? An Empirical Inquiry. International Journal of Comparative Criminology, 3(2), 94-118.

Tanzi, V., \& Davoodi, H. (1997). Corruption, public investment, and growth. Working Paper of the International Monetary Fund, Fiscal Affairs Department, WP/97/139. Available at https://www.imf.org/external/pubs/ft/wp/ wp97139.pdf

Tanzi, V., \& Davoodi, H. (2000). Corruption, Growth and Public Finances. IMF Working Paper.

Transparency International (2010). Exploring the relationships between Corruption and Tax Revenue. Available at url\{https://www.transparency.org/files/content/ corruptionqas/228_Exlporing_the relationships between_corruption_and_tax_revenue.pdf\}

Transparency International (2017). What is corruption? Available at https://www.transparency.org/ what-is-corruption

Treisman, D. (2000). The causes of corruption: A crossnational study. Journal of Public Economics, 76(3), 399457. https://doi.org/10.1016/S0047-2727(99)00092-4

Urra, F.J. (2007). Assessing corruption. An analytical review of corruption measurement and its problems: Perception, error and utility. Washington, DC: Georgetown University.

Valenzuela-Reynaga, R., \& Hinojosa-Cruz, A.V. (2017). Las transferencias federales, los contrapesos políticos y los ingresos fiscales estatales en México. ECONOMÍaunam, 14(42), 47-71.

Van Rijckeghem, C., \& Weder, B. (2001). Bureaucratic corruption and the rate of temptation: do wages in the civil service affect corruption, and by how much? Journal of Development Economics, 65(2), 307-331. https://doi.org/ 10.1016/S0304-3878(01)00139-0

Van Veldhuizen, R. (2011). Bribery and the Fair Salary Hypothesis in the Lab. Working Paper,Tinbergen Institute,
Netherlands. Available at https://www.creedexperiment. $\mathrm{nl} /$ creed/people/veldhuizen/JobMarketPaper.pdf

Vicente Oliva, C. (2010). Ciclos políticos presupuestarios en los ayuntamientos de la Región de Murcia (1989-2008). Tesis de Máster en Ciencias de la Empresa, University of Murcia.

Villoria, M. (2007). La corrupción política, Madrid: Síntesis.

Villoria, M., \& Jiménez, F. (2012). La corrupción en España (2004-2010): datos, percepción y efectos. Revista Española de Investigaciones Sociológicas, 138, 109-134. https://doi.org/10.5477/cis/reis.138.109

Wainstein, M. (2003). La corrupción. Un tema para investigar. Contabilidad y Auditoría, 17(9), 3-76.

Warren, M.E. (2004). What does corruption mean in a democracy? American Journal of Political Science, 48(2), 328343. https://doi.org/10.1111/j.0092-5853.2004.00073.

Wei, S.J. (2000). Natural openness and good government. World Bank Policy Research Working Paper No. 2411, Cambridge MA.

Xu, G., \& Yano, G. (2017). How does anti-corruption affect corporate innovation? Evidence from recent anticorruption efforts in China. Journal of Comparative Economics, 45(3), 498-519. https://doi.org/10.1016/j.jce. 2016.10.001 